\title{
"O OUTRO PÉ DA SEREIA": IDENTIDADE E ALTERIDADE NO ENCONTRO ENTRE CULTURAS
}

Rosilda Alves Bezerra ${ }^{1}$

\begin{abstract}
Resumo: Analisar a identidade e o encontro entre culturas na obra de Mia Couto, em 0 outro pé da sereia, é o objetivo desse artigo. As culturas são divididas em duas expressões: uma que obedece a uma lógica mítica, primordial; e a outra que é estrangeira e letrada. São as diferenças culturais que sobressaem no romance que inicia com o enterro de uma estrela em um descampado de um lugarejo na África chamado Antigamente. Em países novos, recém-saídos de longos e violentos processos de emancipação, a literatura não poderia deixar de ser um dos locais privilegiados para essa discussão e para a representação das tensões entre a cultura do colonizador e dos povos colonizados.

Palavras-Chave: Mia Couto, Identidade, Alteridade, Cultura, M oçambique.
\end{abstract}

\begin{abstract}
The aim of this paper is to analyze aspects of identity and cross-cultural tension in Mia Couto's novel O Outro Pé da Sereia. There are two forms of cultural expression: one which obeys a mythical, primordial logic; one which is foreign and literate. These are the cultural differences highlighted in the novel, which begins with the burial in an open field of an African town called Antigamente (Long Time Ago). In new nations, recently emerged from long and violent processes of emancipation, literature is the ideal locus for this discussion and for representing the tension between the culture of the colonizer and the colonized. Key Words: M ia Couto, Identity, Alterity, Culture, M ozambique.
\end{abstract}

Eis a nossa sina: esquecer para ter passado, mentir para ter destino (0 Barbeiro de Vila Longe).

0 aspecto cultural na obra de Mia Couto é um exemplo vivo de que "a viagem não começa quando se percorrem as distâncias, mas quando se atravessam as nossas fronteiras interiores", como está escrito em 0 outro pé da sereia (COUTO, 2006, p. 65). 0 tema principal do romance é o confronto entre culturas. Uma que obedece a uma lógica mítica, primordial; e a outra que é estrangeira e letrada. São as diferenças culturais que sobressaem no romance que inicia com o enterro de uma estrela em um descampado de um lugarejo na África chamado Antigamente.

1 Mestre em Comunicação e Semiótica, pela PUC/SP; doutora em Literatura e Cultura, pela Universidade Federal da Paraíba - UFPB; professora de Literaturas Africanas e coordenadora da Especialização em Literatura e Cultura Afro-Brasileira, da Universidade Estadual da Paraíba - UEPB, Campus Guarabira; professora do Programa de Pós-Graduação (M estrado) em Literatura e Interculturalidade - MU/UEPB, Campina Grande. Endereço eletrônico: rosildaalvesuepb@yahoo.com.br. 
Para a necessidade de perceber quais as formas de se apreender a literatura africana como existência ou não de uma "africanidade literária", poderíamos aceitar de bom grado o que Mia Couto afirma sobre essa africanidade de existência e não existência: "a africanidade literária existe porque há qualquer coisa que identifica um autor como sendo africano". Ele discorda dessa existência e insiste em afirmar que as identidades de cada ser humano são mutáveis e "viajar pelas identidades é uma possibilidade de ser feliz". M as admite que não escreveria o que escreve se não tivesse vivido a sua vida em M oçambique. A narrativa traz à tona a dimensão sagrada da casa, da terra, do rio, do tempo, traço que se repete em outros romances do autor.

A literatura africana de língua portuguesa contemporânea vem com uma infinidade de autores, com mundos e imagens relacionados, em sua maioria, à guerra, mas que não existem palavras apoéticas para descrever o horror. Não que o horror deva ser descrito de modo poético, mas que a forma de perceber a vida é diferente para que tem a morte tão presente.

De modo geral, nas literaturas contemporâneas de Angola e M oçambique, é inevitável a recorrência de um tema-chave, que norteia a produção poética e a ficcional: a questão da identidade. Em países novos, recém-saídos de longos e violentos processos de emancipação, a literatura não poderia deixar de ser um dos locais privilegiados para essa discussão e para a representação das tensões entre a cultura do colonizador e dos povos colonizados.

Nesse sentido, como enfatiza Eagleton (2005, p. 15),

se somos seres culturais, também somos parte da natureza que trabalhamos.

Com efeito, faz parte do que caracteriza a palavra "natureza" o lembrar-nos da continuidade entre nós mesmos e nosso ambiente, assim como a palavra "cultura" serve para realçar a diferença.

Em 0 outro pé da sereia (2006) a história mostra a inciativa do casal Mwadia Malunga e seu marido, o pastor Zero Madzero, na procura pelo adivinho Lázaro Vivo, um homem que se convertera numa figura mítica, com intuito de pedirem permissão para entrar na floresta e enterrar uma estrela. Naturalmente, a esposa estranha o fato de seu marido pastor querer se consultar com 0 adivinho, uma vez que sua igreja proibia as cerimônias tradicionais. No entanto, Zero Madzero insiste no fato de que "a igreja proíbe, mas, às vezes, a circunstância é maior que a situação" (COUTO, 2006, p. 21). Quando sua mulher decide banhar-se nas águas do rio sagrado, apesar dos protestos do marido, encontra a estátua de Nossa Senhora sem um pé, um esqueleto e um baú com documentos antigos:

entre os verdes sombrios, figurava a estátua de uma mulher branca. Era uma Nossa Senhora, mãos postas em centenária prece. As cores sobre a madeira 
tinham-se lavado, a madeira surgia, aqui e ali, espontânea e nua. 0 mais estranho, porém, é que a Santa tinha apenas um pé. 0 outro havia sido decepado... Ali se exibia as ossadas completas de pessoa humana. 0 pastor recuou como se ao ganhar distância, lhe viesse mais entendimento. Desviou 0 rosto: ao contemplar os ossos ele via o seu próprio esqueleto (COUTO, 2006, p. 38).

Esse episódio não deixa de ser o marco inicial de duas ousadas travessias traçadas pelo sincretismo e pelos contextos históricos, políticos e sociais, que marcaram Moçambique, desde a origem do colonialismo português até 2002. A própria estátua de Nossa Senhora, viajando de Goa para África, transita da religião dos céus para o sagrado das águas. 0 pastor Zero Madzero sugere a mulher que leve até a Vila Longe a estátua de Nossa Senhora para a igreja. M wadia Malunga deseja isso também, temia por alguma punição. Primeiro, porque acreditava que não devia tirar aqueles objetos da floresta; segundo, porque 0 retorno à Vila Longe representava sonho e pesadelo. Possuía 0 desejo de reencontrar os seus familiares, a mãe que sofrera com sua ausência, e de regressar à velha casa de infância, com receio de que nada disso existisse mais.

M wadia irá se deparar com suas reminiscências e medos, distante das consentidas impossibilidades de Antigamente, isto será o elo entre as duas travessias, que se unem com a imagem da Virgem Maria, e a necessidade de desvendar as sombras. Afinal, "quem parte treme, quem regressa teme" (COUTO, 2006, p. 68).

Quando M wadia desconfia que a canoa chegará sozinha quando ela precisar, o curandeiro Lázaro não perde a oportunidade de repreendê-la, realçando em tom de desagrado: "você ficou muito tempo lá no seminário, perdeu o espírito das nossas coisas, nem parece uma africana" (COUTO, 2006, p. 46). M wadia envergonha-se da própria atitude e se desculpa por sua falta de crença. Na verdade, ela não se conhece mais e a distância de suas tradições possibilitou a relevância da credulidade. Enquanto isso, Zero Madzero explica ao curandeiro Lázaro as estranhas ocorrências na floresta, junto ao rio Mussenguezi. Lázaro, aturdido, indaga se o pastor mexeu nos ossos, uma vez que pertencia ao missionário Silveira, e estavam na floresta há mais de quatrocentos anos.

Dessa forma, a Virgem M aria com o pé decepado se divide em dois tempos: na histórica incursão do jesuíta português D. Gonçalo da Silveira, que trouxe a imagem benzida pelo papa para a sua introdução na corte do Império de M onomotapa, em 1560, às margens do rio Zambeze e, em 2002, no retorno de Mwadia à Vila Longe com a missão de introduzir a imagem num lugar sagrado, como podemos perceber na seguinte passagem: 
a estátua de Nossa Senhora, benzida pelo papa, é o símbolo maior desta peregrinação. Silveira jurou que a imagem sagrada só repousaria em terras da $M$ ãe do Ouro, na corte de M onomotapa. Mas a Santa quase ficava em Goa, aprisionada nas lamacentas margens do rio Mandovi. No carregamento do barco, junto à Igreja de Nossa Senhora da Penha de França, a estátua escorregou dos braços do padre Manuel Antunes e tombou no lodo. De imediato, o pântano começou a engolir a imagem. Um escravo acorreu, lançando-se nas águas turvas. Com as pernas enterradas na lama, o homem soergueu a Virgem Santíssima, evitando que fosse tragada do lodoso chão dos trópicos. 0 servo negro abraçou a imagem e banhou-se lentamente na água para Ihe retirar o lodo (COUTO, 2006, p. 51-2).

As construções precisas do início de processo de colonização e da sociedade de M oçambique, em 2002, independente desde 1975, são reveladas nas travessias. A relação entre os portugueses, os indianos e os negros são etnias marcadas, como os rios que deságuam num oceano que, sem margens à vista, é como uma nau à beira do abismo. Assim, o escravo lava a água do rio com a Santa, é ela quem lava o rio inteiro. Por isso a água do rio é considerada santa.

Os acontecimentos dessa viagem que, em certa medida, espelham os eventos contemporâneos, envolvem, ainda, o conflito pessoal do jovem sacerdote $M$ anuel Antunes, que será seduzido pelos ritos e ritmos africanos, e a relação de um escravo, Nimi Nsundi, que recupera a santa.

Em sua terra, a Santa chama-se Kianda, a deusa das águas. 0 escravo era o ajudante de meirinho. Tinha sido capturado no reino do Congo e enviado para Lisboa em troca de mercadorias que o Rei Afonso I mandara vir de Portugal. Nimi Nsundi tinha devoção à Santa, mas Gonçalo da Silveira desconfiava que essa devoção ocultava algo maior.

$\mathrm{Na}$ chegada à Vila Longe, Mwadia, pela "escalada da noite", como diz seu padrasto, 0 indiano que sucedeu Edmundo Capitani, o primeiro pai de M wadia, o goês Rodrigues, se benzeu quando chegou perto da santa trazida por sua enteada. Este agora se chamava Jesustino, sempre mudava de nome nos aniversários, o argumento era que, assim, em "trânsito nominal", acabaria vivendo mais tempo, enganando ou fugindo da morte.

Constança, a mãe disforme e envelhecida, diz à filha que as doenças representam a sua única companhia, agora que as suas filhas se foram e o marido Jesustino transitara de "companheiro para companhia". Quando Mwadia descobre que sua Tia Luzmina se "ausentou" (no lar dos Rodrigues não se pronunciava a palavra morrer), ensaia um pranto, que é censurado pela mãe: "o pranto convoca os espíritos da desgraça" (COUTO, 2006, p. 73).

A mãe explicara que a irmã de Jesustino reclamava que "Eva era indiana, da casta brâmane, e que ela própria, Luzmina Rodrigues, era Nossa Senhora. Estava ali, na recatada Vila Longe, à espera do Espírito Santo que deveria certamente ser um goês de casta elevada" (COUTO, 2006, p. 76).

174 A Cor das Letras - UEFS, n. 9, 2008 
A loucura de Luzmina a levou para a morte: "Luzmina, de facto, falecera. Todavia, em Vila Longe a morte não é exactamente um facto. A tia falecera como é devido naquele lugar: sem nunca chegar a morrer. Quer dizer: a sua alma fica acesa, brilhando entre sombras, suspiros e silêncios" (COUTO, 2006, p. 77).

0 padrasto estava ansioso com a chegada de um casal afro-americano que vinham à Vila Longe para estudar antigas histórias de escravos. Jesustino Rodrigues tinha os olhos claros, deslavados, quase azuis. Dizia que estava mudando de raça, estava cansado de ser "caneco" (goês). A chegada dos estrangeiros (afro-americanos) é aguardada com ansiedade, representa uma fonte de renda para a desolada cidade entregue ao passado. Alguns resistem à chegada dos estrangeiros, principalmente o barbeiro Casuarino, que suspeitava muito de estrangeiros que saiam de suas terras.

0 casal, que chegaria à cidade, representava uma Organização NãoGovernamental de apoio ao continente africano e trazia fundos para gastar em campanhas de redução à pobreza em comunidades rurais na África. Dessa forma, eles também precisavam forjar uma presença para garantirem a sobrevivência com contas superfaturadas para ONGs, que alimentam a pobreza e a autocomiseração de povos rendidos à caridade.

A história da escravatura trará à tona problemas que os moradores preferiam não recordar, como o caso dos vanguni, plural de nguni, grupo étnico proveniente do Norte da África do Sul e que, em meados do século XIX, invadiu o território moçambicano. Os moradores queriam impedir Arcanjo M istura de falar com os americanos para que este não comentasse sobre a outra escravatura que havia entre os negros: "os afro-americanos querem saber só dos brancos que nos levaram a nós para a América" (COUTO, 2006, p. 133).

0 casal era formado por Benjamin Southman, um historiador afroamericano, em busca de suas perdidas raízes africanas. Sua esposa brasileira, Rosie Southman, nasceu e viveu no Brasil, mas morava nos Estados Unidos há quinze anos, onde casou e adquiriu nacionalidade norte-americana.

A preocupação do casal, ao chegar em Moçambique, era a de saber qual a raça do piloto: "Seria negro aquele que conduzia o seu destino? Sem dar conta, Benjamin fez o sinal-da-cruz" (COUTO, 2006, p. 138). Nessa passagem, observamos o receio dos estrangeiros ao serem conduzidos por um piloto moçambicano negro e, no entanto, considerado inferior. A comissão de recepção de Passagem, aldeia que durante o tempo colonial, se pensou em construir uma passagem de nível, mas a linha férrea ficou pela intenção, era formada pelo alfaiate Jesustino Rodrigues, a sua enteada M wadia Malunga, o vizinho Zeca M atambira e o barbeiro Arcanjo M istura. 
As saudações ocorreram em inglês e português, apenas o barbeiro se continha, reservado e afastado. Ele espreitava se os seus compatriotas estariam respeitando a "dignidade nacional". Para os americanos, tudo era motivo de interesse antropológico, pois se impressionavam com a destruição dos edifícios não somente pela guerra civil, mas também por outras guerras, conforme explicava M wadia.

Arcanjo M istura sentenciava: "Estas casas não foram destruídas. Estas casas morreram". Casuarino, temendo a fala de Arcanjo provocar alguma tensão, "desatou a dissertar sobre os amores e as casas, que o amor era uma casa, aliás como lembravam as letras românticas da cantora Roberta Miranda" (COUTO, 2006, p. 143).

A lucidez das falas do barbeiro Arcanjo Mistura, o filósofo da aldeia, obrigado a guardar seu idealismo revolucionário, contrapõe-se com a visão do empresário Casuarino, com a passividade do negro Zeca Matambira, funcionário do desativado correio, que teve de abandonar a carreira de boxeador porque não conseguia bater em brancos ou mulatos, e com vida inerte do goês Jesustino Rodrigues e a sua eterna busca de identidade. Nesse sentido, o goês passava por processos inconscientes de identidade, o que indica os vários estágios de processos inconscientes, como enfatiza Hall (2003, p. 38):

a identidade é realmente algo formado, ao longo do tempo, através de processos
inconscientes, e não algo inato, existente na consciência no momento do nasci-
mento. Existe sempre algo "imaginário" ou fantasiado sobre sua unidade. Ela
permanece sempre incompleta, está sempre em "processo", sempre sendo for-
mada.

Os americanos se hospedaram na residência dos Rodrigues, familiares de M wadia M alunga. Esta percebeu que a visita dos estrangeiros em Vila Longe não era fruto do acaso: "Os americanos atravessavam os séculos e os mares onde se esbatera a sua identidade. E ela viajava no território em que o tempo nega converter-se em memória". Esse é um processo que pode ser relacionado à influência que essas comunidades periféricas estão sempre abertas às influências culturais ocidentais. Para Hall (2003, p. 79),

a idéia de que esses são lugares fechados - etnicamente puros, culturalmente tradicionais e intocados pelas rupturas da modernidade - é uma fantasia ocidental sobre a "alteridade": "uma fantasia colonial" sobre a periferia, mantida pelo Ocidente, que tende a gostar de seus nativos apenas como "puros" e de seus lugares exóticos apenas como "intocados".

Ao notar as fotografias dos ausentes na sala, a brasileira se concentra "na fotografia desbotada de um casal de goeses, vestidos a rigor, em pose de 
gente abastada: ele, apoiado numa bengala; e ela, empunhando um guarda-sol de linho branco" (COUTO, 2006, p. 145).

A brasileira fez um comentário a respeito de uma sombrinha tão grande, aberta no salão. Mas Constança explicava que tal atitude servia para mostrar que naquela altura eles não eram mais pretos. A palavra "preto" fez com que Benjamin pedisse para que não usasse tal expressão, pois não era correto. Era para usar a palavra "negro". No entanto, para os moçambicanos, "negro" é que era considerado um insulto. Esse parece ser um momento definidor dessa questão, como afirma Hall (2003b, p. 72), "uma vez que "negro" - antes um epíteto negativo - tornou-se um termo de identificação cultural positivo, podese falar de uma etnização de raça".

A marcação da palavra está relacionada também ao que Bhabha (2003, p. 73) explora na metáfora da visão de deslocamento da relação colonial,

a presença negra atravessa a narrativa representativa do conceito de pessoa ocidental: seu passado amarrado a traiçoeiros estereótipos de primitivismo e degeneração não produzirá uma história de progresso civil, um espaço para o Socius; seu presente, desmembrado e deslocado, não conterá a imagem de identidade que é questionada na dialética mente/corpo e resolvida na epistemologia da aparência e realidade. Os olhos do homem branco destroçam o corpo do homem negro e nesse ato de violência espistemológica seu próprio quadro de referência é transgredido, seu campo de visão perturbado.

Benjamin explanava sobre seus métodos de abordagem relacionado ao trabalho que desenvolvia, principalmente retornava ao passado colonial, à escravatura. "Era esse estigma que explicava a condição de miséria do continente" (COUTO, 2006, p. 147). 0 americano pretendia fazer entrevistas com a população, o que ele chamou de "entrevista estruturada". No início pediu desculpas por tomar o tempo dos moradores de Vila Longe.

0 primeiro, o empresário Casuarino, homem "palavroso", porém sem dotes de eloqüência, explicava o seguinte para o americano: "Para nós, africanos, o Tempo é todo nosso. O branco tem o relógio, nós temos o Tempo" (COUTO, 2006, p. 148). Benjamin queria saber se ainda existiam memórias de escravatura naquele lugar. Zeca Matambira respondia que todos sofreram muito com os vanguni (traficantes de escravos).

Benjamin assustou-se quando descobriu que esse grupo se tratava de negros que vieram do Sul e escravizaram, capturaram, venderam e mataram as pessoas daquele lugar. Casuarino, o empresário, não concordou com o depoimento de Matambira porque era necessário afirmar aquilo que os afroamericanos queriam ouvir: a escravidão realizada pelos portugueses. Benjamin precisava de uma experiência autenticamente africana, e por essa razão resol- 
veram levá-lo até ao curandeiro Lázaro Vivo, que o americano pensara tratar de um vanguni.

Rosie, a brasileira, solicitou a Constança Malunga, mãe de M wadia, permissão para entrevistá-la. A idéia era saber de suas memórias. A conversa se deu no luande (pátio), com a presença da filha. Rosie era psicóloga e havia recolhido durante anos, relatos de negros encarcerados, verdadeiros testemunhos do inferno: "a prisão é um lugar onde se dorme muito e o sonho substitui o viver. É a única coisa que o sistema não pode encarcerar: os sonhos" (COUTO, 2006, p. 169). Rosie acreditava que havia ligações misteriosas entre as duas margens do Atlântico, sobretudo, nos mitos religiosos. Ela registrava as representações mentais de negros na América e pretendia realizar uma comparação com o imaginário africano. Constança surpreendeu Rosie com o depoimento revelador de que nunca tivera filhos, em um desabafo concernente à solidão: "Vocês é que me tiveram a mim, me sugaram não só os peitos, mas chuparam-me o alento de viver".

A vida miserável de mulher pobre era a sentença da alma feminina africana: "Nela, e só nela, pesaram os vivos, pesaram os falecidos. Esse é o destino da mulher pobre: ser a última a deitar-se e não dormir com medo de não ser a primeira a despertar" (2006, p. 171). Para Constança, era muito bom sonhar com África, de longe, ao dirigir-se à estrangeira sentenciou: “Você, minha irmã, não agüentaria viver aqui..." (2006, p. 177).

Em relação à vida amorosa, Constança não teve receio de dizer que a única coisa que lamentava era ter se tornado demasiado esposa para ser muIher, e agora que estava no fim da vida, podia confessar que as vezes que fez amor com maior paixão foi com mulheres (p. 178). M wadia ficou aterrada com a confissão da mãe, que argumentava: "Vila Longe era uma terra de homens ausentes. Saíam dali adolescentes, sem idade para serem homens. Regressavam doentes, demasiado tarde para serem maridos. Por fim, tornavam-se pais quando as esposas ficavam viúvas" (p. 178).

0 americano desejava entrevistar o barbeiro Arcanjo, que resistia, apesar do apelo do empresário Casuarino, insistente em afirmar que os americanos eram seus irmãos. Porém, o barbeiro não acreditava naquelas pessoas que até tinham medo da palavra preto. Tal afirmação faz-nos lembrar do pensamento de Foucault (2004, p. 55), que diz respeito ao significado das coisas. Para ele, "os discursos são feitos de signos; mas o que fazem é mais que utilizar esses signos para designar coisas. É esse mais que os torna irredutíveis à língua e ao ato da fala. É esse mais que é preciso fazer aparecer e que é preciso descrever". 
A comunidade reuniu-se para forjar uma memória sobre a escravidão, pois pretendia vender uma grande história aos americanos, já relegada ao esquecimento (é necessário esquecer para sobreviver). Benjamin conseguiu entrevistar Arcanjo, apesar deste afirmar que se irritava com o discurso da afirmação dos negros,

Arcanjo M istura permanecia inflexível. Ele vivera o colonialismo e aprendera que os portugueses mais pobres eram, afinal, os mais racistas. 0 mesmo estava sucedendo nos EUA: aqueles pretos que tiveram sucesso converter-se-ão nos mais fervorosos defensores do mesmo sistema que, antes, os discriminou (p. 185).

Para Arcanjo, as pessoas daquele lugar deveriam lutar para deixarem de ser pretos, para serem simplesmente pessoas. Assim, acreditava que para muitos brancos era impossível deixar de ter raça, porque há muito que eles aprenderam a gostar de ser brancos. Ele fazia reflexões sobre a questão de raça e tinha uma opinião fechada: "se ele puxara o tema foi porque o americano exibia a raça como uma doença para que o mundo sentisse comiseração. E usava a cor da pele como empréstimo de identidade" (p. 190).

Benjamin era historiador e caçador de passados, como gostava de se identificar. No momento de reza de M wadia, ele percebeu a imagem da santa que se assemelhava a Mama Wati, uma sereia batizada pelos negros da costa atlântica. Benjamin falava dessa sereia que os africanos fantasiaram a partir da imagem de Nossa Senhora: "Essa sereia viajara com os escravos e ajudara-os a sonhar e a suportar as sevícias da servidão. Essa sereia deixara de ter chão, depois de não mais ter mar. 0 canto que embriagara os navegantes já há muito que havia emudecido" (p. 193).

0 depoimento de Benjamin era uma prova de que ele procurava encontrar uma África que sempre sonhou. Há, nesse aspecto, o tratamento irônico no desejo patético do afro-americano querer ser africano e as discussões sobre a globalização e a "legitimidade" da inevitável "mulatização dos povos". Dessa forma, esta questão se coaduna ao pensamento de Sidekun (2003, p. 250), quando destaca que a "Filosofia Intercultural cria um paradigma interpretativo novo, que opera pela interpretação do próprio e do outro, como resultado da interpelação comum, mútua, em que a voz de cada um e percebida e reconhecida em sua alteridade".

Apesar da curiosidade sobre a origem da santa com o pé decepado, M wadia não sabia inventar uma mentira. Assim, Benjamin explicava que devia ter caído de alguma proa, pois era usual ornamentarem com figuras religiosas os barcos que transportavam os escravos: "Era um modo de santificar o crime, mas também uma maneira de se acrescentar um valor simbólico à viagem. Uma nau já não era apenas uma embarcação. Era um altar flutuante" (p. 193). 
A aldeia chamada Vila Longe atravessava os territórios do sonho, para além das fronteiras da geografia da vida. A chegada dos estrangeiros em Vila Longe renovara o combate contra os próprios moradores em relação ao reconhecimento de sua própria identidade. É a noção de sujeito sociológico, como define Hall (2003a, p. 11),

a identidade é formada na interação entre 0 eu e a sociedade. 0 sujeito tem um núcleo ou essência interior que é o "eu real", mas este é formado e modificado num diálogo contínuo com os mundos culturais "exteriores" e as identidades que esses mundos oferecem.

Zeca Matambira preferia ser conhecido como um simples funcionário dos correios, a uma figura lendária do pugilismo do então chamado "ultramar". À noite cumpria um ritual noturno de reconhecer nos fios de cabelo sua negritude. Neste processo, Zeca desenvolve o que Hall (2003a, p. 13) coloca como sujeito adequado à estrutura: "A identidade costura o sujeito à estrutura. Estabiliza tanto os sujeitos quanto os mundos culturais que eles habitam, tornando ambos reciprocamente mais unificados e predizíveis".

Era no pente, como num espelho, que ele contemplava a sua raça. Tempos sem fim, estudava cada fio de cabelo que ficava prisioneiro nos dentes do pente. Tocava neles para os sentir crespos, enroscados como gavinhas de trepadeira. Aqueles fiozinhos, tão singelos, o empurravam para uma certeza: ele era um preto, tão irreversivelmente negro como todos os de Vila Longe. Depois lavava o pente como se a si mesmo se lavasse. Como se o cabelo fosse uma sujidade na alma, a irrefutável prova de um crime, sem perfeição (p. 213).

Apesar das vitórias, ele confrontou Julito M enha-M enha, um mulato famoso no mundo do boxe. Matambira não passou do primeiro assalto. Depois de vários combates, que vencera com facilidade, sua sorte mudou quando lutou contra Mário Futseka, um branco que saíra da criminalidade para entrar no pugilismo. 0 combate demorou segundos e Zeca fora completamente derrotado.

As pessoas não entenderam o que ocorreu, mas Matambira teve uma grave certeza: "ele só era capaz de bater num negro, num homem de igual raça. A sua cabeça tinha sido ensinada a não se defender de um branco. Nem de um mulato" (p. 219). 0 que ocorre, nesse sentido, é que Hall (2003a, p. 9) destaca em termos de descentração do sujeito. Para ele,

esta perda de um "sentido de si" estável é chamada, algumas vezes, de deslocamento ou descentração do sujeito. Esse duplo deslocamento - descentração do indivíduo tanto de seu lugar no mundo social e cultural quanto de si mesmos constitui uma "crise de identidade" para o indivíduo. 
De uma certa forma, era também o que ocorria com os outros moradores e até com os estrangeiros. M wadia M alunga fora "possuída por espíritos", durante uma entrevista com os estrangeiros. Aqui, misturam-se vivos e mortos, passado e presente, história oficial e crenças locais, símbolos cristãos e ritos africanos, sonho e memória. 0 casal viu naquela apresentação uma autêntica África.

Nas seguintes noites M wadia voltou a ser "visitada pelos Muzimos" (espíritos dos antepassados familiares). Em suas sessões, ela aperfeiçoava as visões, focando lembranças. Benjamin estava em êxtase, porque tudo que Mwadia revelava correspondia à realidade histórica. A mãe, assustada com as diversas semelhanças das histórias, soube mais tarde que a filha lia os velhos documentos de D. Gonçalo da Silveira, durante o dia: e, à noite, visitava 0 quarto dos americanos para espreitar os papéis do casal.

Para Mwadia, "o livro era uma canoa. Esse era o barco que Ihe faltava em Antigamente. Tivesse livros e ela faria a travessia para o outro lado do mundo, para o outro lado de si mesma" (p. 238). M wadia lia trechos sobre a história de Vila Longe, de relatórios de contas da administração colonial à correspondência oficial e anotações de viagens. A palavra - tanto da tradição oral quanto do livro, do documento escrito - é o lugar da construção da identidade, pois é onde se preserva a memória. Afinal, é imperativo, no processo de formação e consolidação da identidade, o questionamento do que deve ou não ser lembrado. A leitura passou a ser feita para a mãe que fez daqueles momentos um alívio da solidão: "o problema da solidão é que não temos ninguém a quem mentir" (p. 239), dizia ela.

As visitas ao sótão tornavam Dona Constança mais feliz, isto fazia parecer que estava viva novamente. Estado que foi interditado pelo marido, Jesustino Rodrigues, "o alfaiate sem alfaiataria, marido sem filhos, indiano sem Índia" (p. 240), que a proibira de visitar o sótão. Segundo ele, Constança teria esquecido as tarefas domésticas, tudo estava jogado às traças. Mas para a estranheza de $M$ wadia, a mãe ficou feliz com a proibição do marido, finalmente Justino a proibira de alguma coisa. No entanto, Constança continuou escutando e inventando fantasias. Mwadia encenava e a mãe fazia às vezes dos afro-americanos.

As contradições, que a comunidade de Vila Longe traziam em sua própria constituição, concretizavam-se na captura e na venda de escravos. A postura colonizadora da Igreja, as matanças e imposições coercivas dos portugueses e dos negros nativos da própria terra são retomadas pela memória e através dos escritos. 0 padre Gonçalo, por exemplo, espantou-se com a declaração de um escravo de que seu pai, chefe de uma aldeia, tinha também es- 
cravos. A prática de aprisionar povos inimigos com o intuito de comercializá-los era bastante comum. 0 escravo Xilundo fora vendido pelo próprio pai Baba Inhamoyo, proprietário e negociantes de escravos,

Xilundo explicou-se: ele era escravo, mas a sua família era proprietária de escra-
vos. Viviam disso: da captura e da venda dos escravos. O pai enviara-o para Goa,
na condição de servo, como punição de graves desobediências. O projecto do pai
era simples: preparar o filho para herdar o negócio da venda de pessoas. No pro-
cesso de ser escravo ele aprenderia a escravizar os outros (COUTO, 2006, p. 258).

As alienações e os esquecimentos são lidos nas palavras, que secaram em Zero Madzero ou na canoa libertada da margem do tempo no rio ou no delírio de Mwadia. Mais uma vez ela entrava em transe, de olhos fechados, apontava em direção ao afro-americano e clamava que Benjamin era mulato. 0 ar ofendido do afro-americano fez com que Casuarino interviesse em favor do estrangeiro, argumentando que, desde Caim, somos todos mulatos.

M wadia acrescentava que o último parente da África de Benjamin era Nimi Nsundi. No entanto, Dia Kumari, que tivera um filho com Nimi Nsundi, fora à América. Ela teria sido escrava de uma fidalga chamada Filipa Caiado, que depois de morta, Dia Kumari resolveu seguir para o Brasil. 0 barco que viajava naufragou e ela foi negociada, comprada por um fazendeiro que a conduziu nas plantações na Virgínia. M wadia relatava a Benjamin a história de sua diáspora familiar. Essa era a reflexão da história que corria como um rio rumo aos oceanos, revertendo na necessidade de reconstruir os pés que representam à realidade das sociedades.

A preocupação maior do empresário Casuarino era de que a estadia dos afro-americanos trouxesse mais aflições que proveitos. Para isso recorreu a uma visita a Lázaro Vivo. Pediu a Singério que fosse antes, preparar terreno, para que pudesse levar o norte-americano em uma excursão pela África mais profunda: "Tudo selvagem, nada de modernices" (p. 270). Com a chegada de Benjamin, Lázaro Vivo cumpria o exótico quadro; Com as perguntas de Benjamin, o curandeiro dissertava sobre a guerra:

A guerra, disse 0 adivinho, é uma serpente que matamos sem pisar a cabeça. Um pequeno descuido e eis que ela ressurge no escondido do capinzal. Desta volta, porém, para nos envenenar a cobra já nem precisa morder. Basta despertar lembrança dos venenos que nos correm nas veias (COUTO, 2006, p. 272).

Lázaro Vivo indagou sobre o paradeiro da Santa levada por M wadia, se já possuía um lugar firme para ficar e aproveitou a ocasião para contar a história de batismo de Mwadia. No momento em que submergiu, a pequena Mwadia começou a entrar em delírio, possuída por um espírito todo-poderoso. Agora Benjamin entendia os poderes de M wadia. Esse era o interesse do ame- 
ricano: ser batizado por Lázaro Vivo. Segundo o adivinho, Benjamin não era feliz porque o nome não lhe assentava bem, ele era um akayendi (uma pessoa sem tribo própria e que espera adotar um nome). No entanto, ele não tinha mais idade de se batizar, de realizar um magoneko (festa de mudança de nome, ao chegar à puberdade).

Benjamin precisava de depoimentos de africanos autênticos e Jesustino não se encaixava no perfil de entrevistado por causa da ligação de sua família ao tráfico de escravos. 0 goês sabia das suas origens, ele descendia de comerciantes de escravos, mas achava que não tinha de pagar por isso. Sentia trauma por ter causado a morte da mãe que faleceu no seu parto. Vida e morte se entrelaçaram na chegada de Jesustino. Para ele, a Índia não mais existia e queria esquecer-se indiano. Quando Singério dava-Ihe as boas vindas em língua da Índia era insuportável escutar tão estranho idioma, pois lembrava o distanciamento existente entre ele e o pai: "Quando isso sucedia, o velho Agnelo se evaporava num outro mundo, para além de um cortinado translúcido" (p. 282).

Benjamin seria batizado e seu novo nome Dere Makanderi era a prova de que voltava às suas origens, de que já não era mais um afro-americano. Agora, que tinha um nome, pouco Ihe interessava pertencer a uma "identidade maior". O novo homem avisara que partiria por algum tempo. Sua ausência provocou insatisfação na cidade, principalmente de quem necessitava da renda que o estrangeiro proporcionava, como o empresário Casuarino.

Para Rosie, a ausência do companheiro não lhe causara surpresa, ele queria solver-se em lugar que era somente dele, precisava desse espaço de redenção: "sabia, desde o início, que a peregrinação à África iria degenerar em drama. Desde sempre, ela estranhara a obsessão do marido pelo retorno ao continente dos seus antepassados. Quem pode apostar tanto o presente num passado tão longínquo?" (p. 293). Zeca Matambira procurava consolar Rosie, afirmando que Benjamin teria que procurar a África na América, ou dentro dele mesmo. Mas Zeca não fazia idéia de quanto era difícil existir num mundo que exigia que se tivesse a raça certa e a acertada riqueza. Nesse momento, Rosie se percebia brasileira, agora mais do que nunca. Tal afirmação tem relação direta com o pensamento de Silva (2000, p. 75-6),

quando digo "sou brasileiro" parece que estou fazendo referência a uma identidade que se esgota em si mesma. "Sou brasileiro" - ponto. Entretanto, eu só preciso fazer essa afirmação porque existem outros seres humanos que não são brasileiros. Em um mundo imaginário totalmente homogêneo, no qual todas as pessoas partilhassem a mesma identidade, as afirmações de identidade não fariam sentido. De certa forma, é exatamente isto que ocorre com nossa identidade de "humanos". É apenas em circunstâncias muito raras que precisamos afirmar que "somos humanos". 
Zeca Matambira confessava a Rosie que também sofrera discriminação por ser negro, ele nunca tinha sido capaz de superar o seu constrangimento, "e recordou o creme para aclarar a pele, os produtos para desencrespar o cabelo, a ocultação da sua origem humilde. Sim, a sua existência tinha sido um permanente e nunca alcançado disfarce" (p. 294).

0 homem que sentia vergonha de sua negritude agora estava ao lado de uma mulher que lhe acariciava o cabelo crespo, mesmo se desviando com a agilidade de um boxer: "Não, 0 cabelo, não" (p. 297), porém, as mãos de Rosie avançaram sobre ele, envolvendo-lhe a testa e descendo pelos ombros. Ao lado do pugilista, Rosie declarava: "Eu só quero chorar, deixe-me chorar. Chorar junto pode ser melhor do que fazer amor..." (p. 298).

A imagem de Nossa Senhora, ou Nzuzu, ou Kianda, deslizava nos cursos das travessias. M wadia procurava a igreja para fazer dela a morada da santa. 0 barbeiro lembrava que ela nunca encontraria uma morada, pois apesar de existir igreja, o que faltava era a crença. Os pés da santa representavam M wadia, eles unem e sustentam a travessia dos sonhos e histórias. Ela precisava deixar que a Santa a conduzisse a si e atendeu ao pedido do barbeiro que pediu para que a Santa dormisse com ele uma noite e que Mwadia partisse 0 quanto antes de Vila Longe.

Existem crenças que não precisam de alicerces em solo firme, são como água, ar, vento e se equilibram no ventre das palavras e dos silêncios. M wadia descobriu que a mãe não tinha engordado e era infeliz por causa de sua ausência e sim para agüentar os constantes espancamentos do marido: "Com mais carne, as pancadas doíam menos" (p. 322), revelava o segredo, Zeca M atambira. A mãe explicava que fazia aquilo para proteger o seu marido, o padrasto Jesustino Rodrigues: " $O$ soco dói mais a quem bate do que a quem é batido. Sobretudo, se 0 agredido não é bem enchido. Foi então que Constança se empenhou em ganhar volume. Para que Justino não se magoasse quando a agredia" (p. 323). Ou melhor, para que o marido não sentisse as dores do reumatismo, que Ihe aplacavam o corpo quando batia em alguém magro.

A brasileira emocionou-se com a revelação de Constança e consolou a anfitriã. Constança agradeceu o carinho e indagou se Rosie ficaria mais tempo em Vila Longe. A brasileira resolveu voltar para o Brasil: "Esta viagem me fez entender quem sou, de onde eu sou..." (p. 323). Rosie explicava que o dinheiro trazido pelo casal era de uma associação religiosa afro-americana, a Save África Fund.

Benjamin vivia de esquemas. Era assim que ele ganhava a vida. Confessou que Benjamin e Zeca M atambira eram cúmplices desde o início. Casuarino, o empresário, que se achava esperto, era o mais enganado, porém era o finan- 
ciador americano que se empenhava na salvação dos irmãos africanos. 0 que era verdadeiro em Benjamin era o fato dele realmente ser historiador, a paixão pela África e a procura de seu passado africano. Por fim, Benjamin estaria no Zimbabwe. As mulheres se despediram.

M wadia informou que estava de partida para Antigamente, precisava voltar para Zero M adzero. A mãe lembrou a filha que Zero fora morto há muito tempo, e quando ela soube da notícia, enlouqueceu e fugiu para o lugar, além das montanhas, onde viveu com os burros e os cabritos. M wadia queria saber quem afinal assassinou seu marido. A mãe respondeu que 0 assassino era seu padrasto, Jesustino Rodrigues, e explicava:

o assassínio, pensamos, nasce da torpeza da alma. Mas não: a vontade de matar
nasce das miudezas do dia-a-dia, desse amarelecer sem história em que se con-
vertem as nossas vidas. Não são os grandes traumas que fabricam as grandes
maldades. São, sim, as miúdas arrelias do quotidiano, esse silencioso pilão que
vai esmoendo a esperança, grão a grão (p. 327-8).

As estrelas, quando expostas ao mundo, trazem à tona o brilho das pequenas estrelas que precisam de um firmamento próprio para crescerem e iluminarem as realidades. A realidade de M wadia era de que o marido comporia a parede dos ausentes. M wadia fazia a viagem do regresso. No fim desta viagem, a mulher reúne os restos do seu passado e enterra definitivamente os seus mortos: "A viagem termina quando encerramos as nossas fronteiras interiores. Regressamos a nós mesmos, não a um lugar" (p. 329). Este é um livro de viagens dentro da história de cada personagem. Para recuperar as memórias perdidas, é preciso viajar até ao interior de nós próprios, ao passado, à nossa própria história.

\section{REFERÊNCIAS}

BHABHA, Homi. O local da cultura. Belo Horizonte: Ed. UFM G, 2003.

COUTO, Mia. O outro pé da sereia. São Paulo: Cia. das Letras, 2006.

EAGLETON, Terry. A idéia de cultura. Trad. Sandra Castello. São Paulo: Ed. UNESP, 2005.

FOUCAULT, M ichel. A arqueologia do saber. Trad. Luiz Felipe Baeta Neves. 7. ed. Rio de Janeiro: Forense Universitária, 2004.

HALL, Stuart. A identidade cultural na pós-modernidade. Trad. Tomaz Tadeu da Silva e Guacira Lopes Louro. 8. ed. Rio de Janeiro: DP\&A, 2003a.

HALL, Stuart. Da diáspora: identidades e mediações culturais. Trad. Adelaine La Guardiã Resende et al. Belo Horizonte: Ed. UFM G; Brasília: Representações da UNESCO no Brasil, 2003b.

SILVA, Tomaz Tadeu da. (Org.). Identidade e diferença: a perspectiva dos estudos culturais. Petrópolis: Vozes, 2000.

SIDEKUN, Antônio. Alteridade e interculturalidade. In: SIDEKUN, A. (Org.). Alteridade e multiculturalismo. Ijuí: Ed. Unijuí, 2003. 
